\title{
ANALISIS PENCAPAIAN STRATEGI \\ MENGGUNAKAN BALANCED SCORECARD DI PERBASI KOTA SURABAYA
}

Disusun Oleh:

Jan Misael Panagan

11117003

FAKULTAS EKONOMI DAN BISNIS

UNIVERSITAS NAROTAMA

SURABAYA

2018 


\section{ABSTRAK}

Bolabasket merupakan salah satu olahraga yang semakin digemari di kalangan muda Indonesia, termasuk di Kota Surabaya. Bertambahnya peminat dan pertandingan-pertandingan bolabasket di Kota Surabaya, mulai dari tingkat sekolah dasar sampai mahasiswa, menjadi bukti bahwa bolabasket mengalami perkembangan yang sangat pesat. Namun berkembangnya bolabasket tidak berbanding lurus dengan prestasi bolabasket Kota Surabaya.

Pencapaian suatu prestasi di bidang olahraga bolabasket pada dasarnya merupakan hasil akumulatif dari berbagai aspek yang mendukung, salah satu yang paling penting adalah pelatih. Ada banyak informasi kepelatihan yang dibutuhkan oleh pelatih bolabasket dalam menunjang karir kepelatihannya, seperti informasi mengenai metode latihan, cara melatih sebuah tim berdasarkan usia atau tingkat permainan, strategi dalam bertahan dan menyerang, data statistik pertandingan dan kondisi fisik seorang pemain, perubahan peraturan pertandingan dan cara mengelola sebuah tim. Namun para pelatih di Kota Surabaya kesulitan dalam mendapatkan informasi-informasi tersebut karena keterbatasan referensi. Selain itu pelatih juga tidak memiliki media untuk dapat saling berbagi pengetahuan.

Sebagai yang paling bertanggung jawab atas prestasi bolabasket Kota Surabaya, maka Perbasi Kota Surabaya harus bisa menyusun rencana strategi yang baik untuk bisa memberikan pelayanan terbaik terhadap anggotanya, khususnya para pelatih bolabasket. Untuk mengukur pencapaian strategi Perbasi Kota Surabaya selama ini dapat digunakan Balanced Scorecard sebagai alat ukur berbasis strategi, meliputi financial prespective, internal process business prespective, customer perspective dan learning and growth perspective. Pendekatan penelitian yang digunakan adalah pendekatan deskriptif kualitatif dengan menggunakan metode studi observasi dan wawancara. Berdasarkan Analisis pencapaian strategi menggunakan balanced scorecard pada strategi yang digunakan oleh Perbasi Kota Surabaya dalam meningkatkan kualitas di Kota Surabaya telah tercapai dengan baik.

Kata Kunci: strategi, balanced scorecard, kinerja 


\section{PENDAHULUAN}

Bolabasket merupakan salah satu olahraga yang semakin digemari di kalangan muda Indonesia, termasuk di Kota Surabaya. Bertambahnya peminat dan pertandingan-pertandingan bolabasket di Kota Surabaya, mulai dari tingkat sekolah dasar sampai mahasiswa, menjadi bukti bahwa bolabasket mengalami perkembangan yang sangat pesat. Hal tersebut membuat bolabasket menjadi olahraga yang bergengsi dan trend di kalangan anak muda di Kota Surabaya.

Namun berkembangnya bolabasket tidak berbanding lurus dengan prestasi bolabasket Kota Surabaya. Meskipun bolabasket Kota Surabaya masih lebih baik jika dibandingkan dengan daerah-daerah lainnya di Jawa Timur, namun masih tetap kalah dengan daerah-daerah dari luar Jawa Timur. Hal tersebut dapat terlihat dari jumlah pemain dan pelatih yang terpanggil untuk memperkuat tim bolabasket Indonesia (Timnas). Pada tahun 2013 hanya 3 pemain dan 1 pelatih asal Kota Surabaya yang terpilih untuk memperkuat Timnas di ajang bolabasket tingkat Asia Tenggara, sedangkan pada tahun 2015 turun menjadi 1 pemain saja yang terpanggil untuk bermain di ajang yang sama. Prestasi bolabsaket Kota Surabaya juga dapat dikatakan menurun, jika dilihat dari minimnya prestasi tim bolabasket Jawa Timur usia 18 di tingkat nasional, yang sebagian besar anggotanya selalu berasal dari Kota Surabaya.

Pencapaian suatu prestasi di bidang olahraga bolabasket pada dasarnya merupakan hasil akumulatif dari berbagai aspek yang mendukung, salah satu yang paling penting adalah pelatih. Kemampuan seorang pelatih adalah salah satu kunci utama dalam keberhasilan sebuah tim. Pelatih adalah orang yang harus tahu tentang semua kebutuhan yang menjadi dasar bagi terpenuhinya kondisi dimana pemain atau tim yang dibinanya memiliki peluang untuk mencapai prestasi. Pelatih memiliki tugas sebagai perencana, pemimpin, teman, pembimbing, dan pengontrol program latihan, sedangkan pemain mempunyai tugas melakukan latihan sesuai program yang telah ditentukan pelatih [BRO84]. Menurut seorang pelatih bolabasket asal Amerika melalui situs resmi bolabasket USA, ada 5 hal yang mencerminkan seorang pelatih yang baik, yaitu mengajarkan cara berperilaku yang baik sebagai seorang pemain, memiliki kebiasaan yang baik 
dalam melatih, memiliki metode latihan yang baik, memiliki strategi pertandingan yang efektif dan dapat menyatukan seluruh anggota tim. Selain itu seorang pelatih juga harus tahu karakteristik pemain dan tim yang sedang mereka tangani, sehingga mereka dapat menerapkan hal yang tepat kepada pemain atau tim teresebut. Untuk dapat mencapai hal-hal tersebut dibutuhkan lebih dari sekedar pengalaman saat menjadi seorang pemain atau pengalaman saat melatih.

Ada banyak informasi kepelatihan yang dibutuhkan oleh pelatih bolabasket dalam menunjang karir kepelatihannya, seperti informasi mengenai metode latihan, cara melatih sebuah tim berdasarkan usia atau tingkat permainan, strategi dalam bertahan dan menyerang, data statistik pertandingan dan kondisi fisik seorang pemain, perubahan peraturan pertandingan, cara mengelola keuangan tim saat bertanding ke luar kota, dan lain-lain. Informasi-informasi tersebut bisa didapatkan melalui buku, video, internet atau pengalaman. Namun berdasarkan kuisioner yang dibagikan kepada 70 pelatih di Kota Surabaya yang dapat dilihat pada lampiran B, sebanyak $85,7 \%$ mengalami kesulitan dalam mendapatkan informasi-informasi tersebut. Sampai saat ini di Indonesia tidak dijual buku atau video mengenai bolabasket. Meskipun bisa dibeli melalui internet, namun sebagian besar pelatih tetap tidak dapat membeli karena kendala dana. Di internet juga sudah banyak situs-situs bolabasket yang baik, namun karena informasinya beragam dan tidak memiliki format yang dapat mempermudah penyerapan informasi, maka banyak dari para pelatih yang kesulitan dalam memahami isi informasi yang ditampilkan. Kendala bahasa juga menjadi kesulitan para pelatih dalam memahami informasi yang dibagikan melalui buku, video dan internet, karena sebagian besar informasi dibagikan menggunakan bahasa Inggris. Sedangkan situs bolabasket berbahasa Indonesia yang banyak beredar hanya berupa blog, yang isinya hanya mengulas tentang olahraga bolabasket secara umum, sehingga informasi yang dibagikan bukan informasi yang dibutuhkan dan tidak dapat dijadikan sumber informasi untuk melatih.

Informasi-informasi mengenai kepelatihan bolabasket yang seharusnya bisa didapatkan melalui diskusi antar pelatih juga belum bisa terwujud, karena diskusi antar pelatih belum menjadi sebuah kebiasaan. Sarasehan, kegiatan 
Perbasi Kota Surabaya yang bertujuan untuk membiasakan para pelatih untuk berdiskusi dan berbagi tidak dapat berjalan dengan baik karena kendala tempat dan waktu, yang membuat peserta yang hadir terlalu sedikit. Selain itu belum ada juga pelatih yang memiliki situs pribadi yang dapat digunakan untuk berbagi pengalaman dan pengetahuannya dalam melatih. Hal ini membuat pelatih-pelatih tidak memiliki tempat untuk bertukar pikiran, juga untuk berbagi pengalaman dan pengetahuan.

Perbasi Kota Surabaya sebagai pihak yang memiliki tanggung jawab paling besar atas bolabasket Kota Surabaya, masih belum bisa memberi solusi atas pemasalahan pelatih yang kesulitan dalam berbagi dan mendapatkan informasi. Selama ini pembinaan pelatih yang masih rutin dilakukan oleh Perbasi Kota Surabaya hanya dua, yaitu penataran pelatih dan penyegaran pelatih. Penataran pelatih adalah kegiatan pemberian materi-materi kepelatihan bagi orang-orang yang ingin menjadi pelatih dan mendapatkan lisensi pelatih, sedangkan penyegaran adalah seminar dengan topik tertentu untuk memperpanjang masa aktif lisensi pelatih. Kedua kegiatan tersebut tidak cukup untuk memenuhi seluruh kebutuhan informasi para pelatih. Karena Perbasi Kota Surabaya belum bisa memberikan pembinaan yang baik, maka para pelatih tetap kesulitan dalam mendapatkan informasi yang mereka butuhkan. Hal ini membuat kinerja Perbasi Kota Surabaya menjadi perhatian bagi para pelatih di Surabaya.

Selama ini belum ada metode khusus yang dilakukan untuk mengukur kinerja Perbasi Kota Surabaya. Pengukuran kinerja berguna untuk menilai apakah strategi yang digunakan oleh Perbasi Kota Surabaya dalam memajukan pelatih bolabasket di Kota Surabaya sudah baik dan tepat sasaran. Oleh karena itu diperlukan sebuah metode pengukuran kinerja untuk memberi penilaian atas kinerja Perbasi Kota Surabaya.

Metode yang dapat digunakan sebagai alat ukur kinerja bagi Perbasi Kota Surabaya adalah Balanced Scorecard. Balanced Scorecard adalah alat ukur berbasis strategis yang meliputi financial perspective, customer perspective, internal process business perspective dan learning and growth. Dengan menggunakan Balanced Scorecard diharapkan dapat membantu Perbasi Kota 
Surabaya dalam mengukur kinerja dan pencapaian mereka.

Mengingat bahwa pengetahuan merupakan aset utama dalam melatih bolabasket, maka perlu dilakukan usaha agar para pelatih di Kota Surabaya bisa mendapatkan informasi kepelatihan yang mereka butuhkan dengan cepat dan mudah. Usaha yang dapat dilakukan oleh Perbasi Kota Surabaya adalah mengembangkan sebuah media bagi pelatih bolabasket untuk bisa saling berbagi pengetahuan dalam melatih bolabasket, lalu menyimpan, mengelola dan menyebarkan pengetahuan tersebut dengan format dan struktur tertentu, sehingga pengetahuan tersebut dapat dipahami dan digunakan dengan cepat dan mudah.

\section{TINJAUAN PUSTAKA}

\section{Manajemen Strategi}

Manajemen strategi adalah sekumpulan keputusan dan tindakan yang diambil oleh para manajer, untuk menentukan performa jangka panjang dari sebuah perusahaan (Hunger \& Thomas. L. Wheelen, 2004). Hal ini termasuk pemindaian lingkungan (eksternal dan internal), formulasi strategi (strategi atau perencanaan jangka panjang), implementasi strategi, serta evaluasi dan control. Manajemen strategi digunakan untuk meningkatkan proses pengawasan dan evaluasi kesempatan-kesempatan dan ancaman yang mungkin terjadi akibat dari kekuatan dan kelemahan sebuah perusahaan.

Manajemen strategi terdiri atas Sembilan tugas penting:

1. Merumuskan misi perusahaan, termasuk pernyataan yang luas mengenai maksud, filoso fi dan sasaran perusahaan.

2. Melakukan analasis yang mencerminkan kondisi dan kapabilitas internal perusahaan.

3. Menilai lingkungan eksternal perusahaan, termasuk faktor persaingan dan faktor kontekstual umum lainnya.

4. Menganalisis pilihan-pilihan yang dimiliki oleh perusahaan dengan cara menyesuaikan sumberdayanya dengan lingkungan eksternal.

5. Mengidentifikasi pilihan yang paling menguntungkan dengan cara mengevaluasi setiap pilihan berdasarkan misi perusahaan. 
6. Memilih satu set tujuan jangka panjang dan strategi utama yang akan menghasilkan pilihan paling menguntungkan tersebut.

7. Mengembangkan tujuan tahunan dan strategi jangka pendek yang sesuai dengan tujuan jangka panjang dan strategi utama yang telah ditentukan.

8. Mengimplementasikan strategi yang telah dipilih melalui alokasi sumber daya yang telah dianggarkan, dimana penyesuaian antara tugas kerja, manusia, struktur dan sistem penghargaan ditekankan.

9. Mengevaluasi keberhasilan proses strategis sebagai masukan pengambilan keputusan di masa mendatang.

Sebagaimana diindikasikan kesembilan tugas tersebut, manajemen strategi mencakup perencanaan, pengarahan, pengorganisasian dan pengendalian atas keputusan dan tindan terkait strategi perusahaan.

Manajemen strategis memungkinkan suatu organisasi untuk proaktif membentuk masa depannya; memungkinkan sebuah perusahaan memulai dan memengaruhi (bukan sekedar respon) aktivitas, sehingga memiliki kontrol terhadap nasibnya. Secara historis, manfaat utama manajemen strategi telah membantu organisasi memformulasikan strategi yang lebih baik dengan menggunakan pendekatan yang lebih sistematik, logis dan rasional untuk pilihan strategi. Dengan demikian diharapkan semakin banyak institusi dan korporasi yang menggunakan manajemen strategi untuk membuat keputusan yang efektif. Meski demikian, manajemen strategi tidak selalu menjamin keberhasilan, dan menjadi disfungsional apabila digunakan secara serampangan.

\section{Balanced Scorecard (BSC)}

Balanced Scorecard pertamakali diperkenalkan oleh Kaplan dan Norton di Harvard Business RevueEdisi Januari-Februari 1992 yang merupakan salah satu alat manajemen strategi yang terdiri dari satu rangkaian pengukuran yang dapat memberikangambaran non keuangan. Balanced Scorecard cocok satu sama lain dengan activity based responsibility accounting, karena Balanced Scorecard memfokuskan pada proses dan memerlukan penggunaan informasi berbasis aktfifitas untuk menerapakan banyak tujuan dan tolakukurnya. Balanced Scorecard merupakan suatu sistem manajemen strategi yang menjabarkan visi dan 
strategi suatu perusahaan ke dalam tujuan operasional dan tolak ukur. Tujuan dan tolak ukur dikembangkan untuk setiap 4 (empat) perspektif yaitu: perspektif keuangan, perspektif pelanggan, perspektif proses usaha dan perspektif pembelajaran dan pertumbuhan. Balanced Scorecard menurut Kaplan dan Norton (2001: 117) ukuran kinerja keuangan saja tidaklah cukup untuk menilai kinerja perusahaan yang diharapkan berhasil di masa depan tetapi juga harus memperhatikan empat aspek ukuran kinerja yaitu: perspektif belajar dan tumbuh (learning and growth perspective), perspektif proses internal/ bisnis (customer perspective), dan perspektif keuangan (financialperspective). Manfaat Balanced Scorecard bagi perusahaan menurut (Robert S.Kaplan, 2001) adalah sebagai berikut: (1) Balanced Scorecard mengintegrasikan strategi dan visi perusahaan untuk mencapai tujuan jangka pendek dan jangka panjang; (2) Balanced Scorecard memungkinkan manajer untuk melihat bisnis dalam perspektif keuangan dan non keuangan (pelanggan, proses bisnis internal, dan belajar dan bertumbuh), dan (3) Balanced Scorecard memungkinkan manajer menilai apa yang telah mereka investasikan dalam pengembangan sumber daya manusia, sistem dan prosedur demi perbaikan kinerja perusahaan dimasa mendatang. Balanced Scorecard yang dirancang dengan baik mengkombinasikan antara pengukuran keuangan dari kinerja masa lalu dengan pengukuran daripemicu kerja masa depan perusahaan. Balance Scorecard adalah metodologi perangkat evaluasi dengan empat perspektif yang dikembangkan oleh Norton dan Kaplan. Balanced Scorecard menilai kinerja suatu organisasi atau perusahaan dalam suatu rentang waktu tertentu (Maiga \& Jacobs, 2003). Banyak strategi eksekusi yang sudah ada, strategi visi dan alat formulasi strategi telah dikembangkan (Luis, S., Biromo, P. A. ,Hadisubrata, R., Andika, A., \& Margana, 2011). Alat perencanaan strategi, termasuk strategy maps dan Balanced Scorecard, telah tersedia untuk digunakan oleh perusahaan lebih dari 10 tahun. Dan hampir semua perusahaan menggunakan alat operasional untuk manajemen kualitas, peningkatan proses, dashboards, dan activity-based costing. Bagaimanapun, kekurangannya adalah kerangka komprehensif untuk mengintegrasikan semua peralatan tersebut, sehingga sebagaimana mestinya dapat menjadi selaras dan sinkron. 


\section{Tahapan Penyusunan Balanced Scorecard}

Langkah pertama adalah menentukan visi, misi dan sasaran strategis. Visi merupakan pernyataan yang berisi gambaran keadaan organisasi yang ingin dicapai di masa yang akan datang. Visi menjawab pertanyaan "kita ingin menjadi apa?". Misi menerangkan cara yang harus dilakukan sebagai wujud penjabaran visi yang telah ditetapkan. Dalam konsep balanced scorecard, visi dan misi yang telah diformulasikan selanjutnya diterjemahkan dalam sejumlah sasaran strategis. Sasaran strategis didefinisikan sebagai pernyataan tentang yang ingin dicapai (sasaran strategis bersifatoutput/ outcome) atau apa yang ingindilakukan (sasaran strategis bersifatproses) atau apa yang seharusnya kita miliki (sasaran strategis bersifat input). Langkah kedua adalah menyusun peta strategi. Peta strategi merupakan suatu dashboard (panel instrument) yang memetakan sasaran strategis organisasi dalam suatu kerangka hubungan sebab akibat yang menggambarkan keseluruhan perjalanan strategi organisasi. Peta strategi memudahkan organisasi untuk mengkomunikasikan keseluruhan strateginya kepada seluruh anggota organisasi dalam rangka pemahaman demi suksesnya pencapaian tujuan organisasi. Unit organisasi yang menyusun peta strategi adalah unit organisasi yang mendefinisikan visi dan misinya dengan jelas serta memiliki proses manajemen yang lengkap (input sumber daya, proses internal dan output/ outcome). Langkah ketiga adalah perspektif balanced scorecard. Kaplan dan Norton (Robert S. Kaplan, 2001) menggunakan empat standar perspektif balanced scorecard yaitu: (1) perspektif keuangan, yaitu balanced scorecard dibangun dari studi pengukuran kiner jadi sector bisnis, sehingga yang dimaksud dengan perspektif keuangan di sini adalah terkait dengan financial sustainability. Perspektif ini digunakan oleh shareholder dalam rangka melakukan penilaian kinerja organisasi. Apabila dinarasikan akan berbunyi "organisasi harus memenuhi sebagaimana harapan shareholder agar dinilai berhasil oleh shareholder; (2) perspektif pelanggan, yaitu perspektif yang berorientasi pada pelanggan karena merekalah pemakai produk/ jasa yang dihasilkan organisasi. Dengan kata lain, organisasi harus memperhatikan apa yang diinginkan oleh pelanggan; (3) Perpektif proses bisnis internal, yaitu serangkaian aktivitas yang ada dalam 
organisasi untuk menciptakan produk/ jasa dalam rangka memenuhi harapan pelanggan. Perspektif ini menjelaskan proses bisnis yang dikelola untuk memberikan layanan dan nilai-nilai kepada stakeholder dan customer, dan (4) Perspektif pembelajaran dan pertumbuhan, yaitu perspektif yang menggambarkan kemampuan organisasi untuk melakukan perbaikan dan perubahan dengan memanfaatkan sumber daya internal organisasi. Kesinambungan suatu organisasi dalam jangka panjang sangat tergantung pada perspektif ini. Langkah keempat adalah menentukan Key Performance Indicator (KPI). Setelah peta strategi disusun, maka langkah selanjutnya adalah menentukan Key Performance Indicator (KPI) untuk setiap Sasaran Strategis (SS). KPI adalah alat ukur bagi pencapaian SS. KPI dibedakan menjadi KPI lagging dan KPI leading. KPI lagging adalah KPI yang bersifat outcome/ output atau yang mengukur hasil, umumnya di luar kendali unit yang bersangkutan. KPI leading adalah KPI yang bersifat proses, yang mendorong pencapaian KPI lagging. Umumnya KPI leading berada di bawah kendali unit organisasi. Dalam perumusan KPI seyogyanya memenuhi karakteristik indikator kinerja yang baik dan cukup memadai guna pengukuran kinerja menggunakan prinsip SMART-C, yaitu: (1) Specific, KPI harus mampu menyatakan sesuatu yang khas/ unik dalam menilai kinerja suatu unit kerja: (2) Measurable, KPI yang dirancang harus dapat diukur dengan jelas, memiliki satuan pengukuran, dan jelas pula cara pengukurannya: (3) Achievable, KPI yang dipilih harus dapat dicapai oleh penanggung jawab atau Unit In Charge; (4) Relevant, KPI yang dipilih dan ditetapkan harus sesuai dengan visi dan misi, serta tujuan strategis organisasi; (5) Time-bounded, KPI yang dipilih harus memiliki batas waktu pencapaian, dan (6) Continuously Improve, KPI yang dibangun menyesuaikan dengan perkembangan strategi organisasi. Selanjutnya, kualitas IKU ditentukan oleh:

1. Tingkat validitas IKU. Validitas suatu IKU ditentukan berdasarkan tingkat kedekatan IKU tersebut dengan tujuannya (SS) sebagaimana nampak pada gambar 1 . 


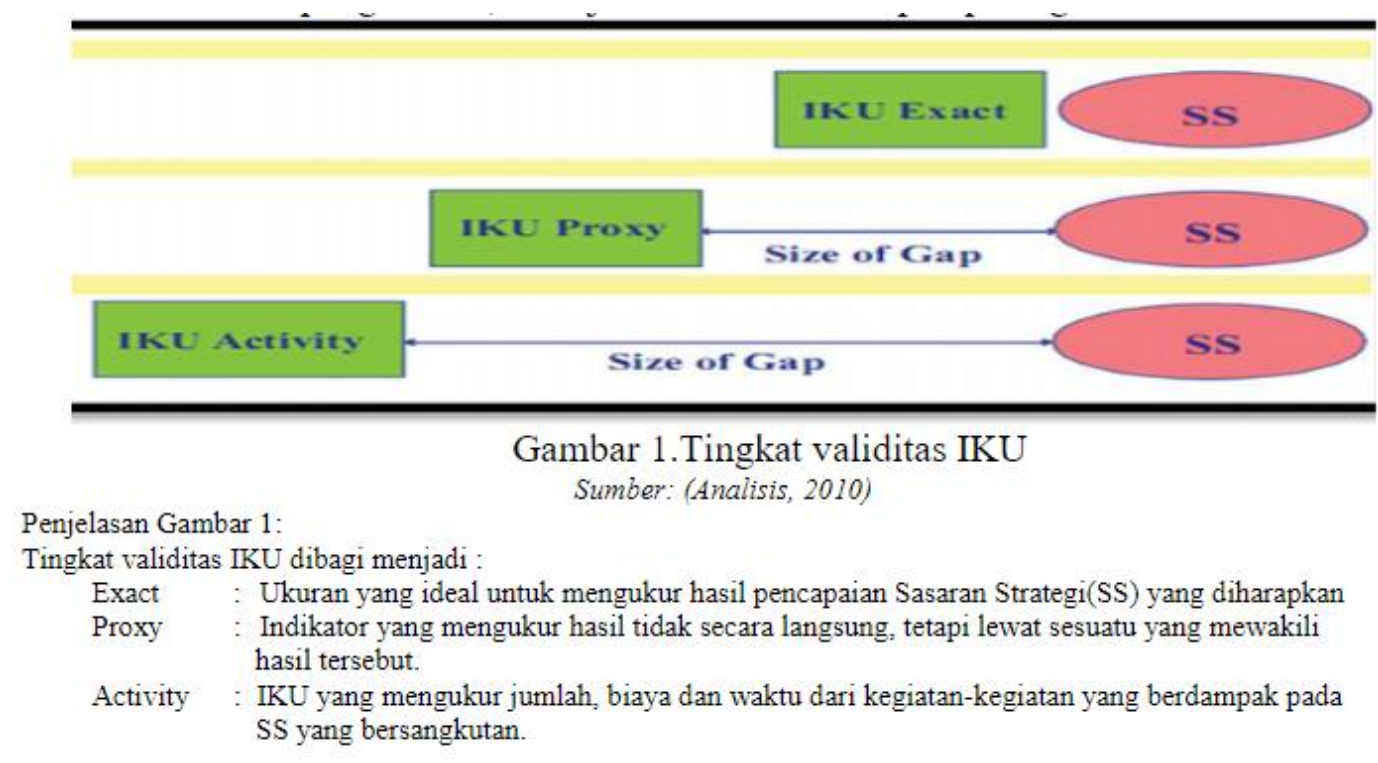

2. Degree of controllability, yaitu menunjukkan sejauh mana kemampuan suatu organisasi dalam mengontrol/ mengelola pencapaian target IKU: (1) High, bermakna pencapaian target secara dominan ditentukan oleh unit/ individu yang bersangkutan; (2) Moderate, yang bermakna pencapaian target juga ditentukan oleh unit/ individu lain; dan (3) Low, yaitu pencapaian target sangat dipengaruhi oleh unit/ individu lain.

Setiap IKU yang ditetapkan harus dilengkapi dengan manual IKU. Manual IKU berisi berbagai informasi tentang IKU seperti deskripsi IKU, formula IKU, degree of controllability dari IKU, jenis IKU, pihak yang mengukur IKU, sumber data, satuan pengukuran, jenis konsolidasi data, polarisasi data, dan periode pelaporan:

1. Jenis konsolidasi data, menunjukkan pola penetapan atau penghitungan angka capaian IKU yang terdiri atas: (a) Sum, yaitu penjumlahan angka capaian per periode pelaporan; (b) Take last known value, yaitu angka capaian yang digunakan adalah angka periode terakhir, dan (3) Average, yaitu rata-rata dari penjumlahan angka capaian per periode pelaporan.

2. Polarisasi data, yaitu menunjukkan ekspektasi arah nilai aktual dari IKU dibandingkan relatif dengan nilai target: (a) Maximize, yaitu 
nilai aktual/ realisasi/ pencapaian IKU diharapkan lebih tinggi dari target; (b) Minimize, yaitu nilai aktual/ realisasi/ pencapaian IKU diharapkan lebih kecil dari target, dan (c) Stabilize, yaitu nilai aktual/ realisasi/ pencapaian IKU diharapkan dalam satu rentang target tertentu. Polarisasi data ini digunakan untuk menentukan status capaian IKU yang secara umum menggunakan perhitungan sebagai berikut:

Tabel 1. Jenis Polarisasi Data

\begin{tabular}{|c|c|c|c|}
\hline \multicolumn{3}{|c|}{ Polarisasi } & \multirow{2}{*}{ Status } \\
\hline Maximize & Minimize & Stabilize & \\
\hline$x<80 \%$ & $x>120 \%$ & $\begin{array}{c}x<80 \% \text { atau } \\
x>120 \%\end{array}$ & Merah \\
\hline $80 \% \leq x<100 \%$ & $100 \%<x \leq 120 \%$ & $\begin{array}{c}80 \% \leq x<90 \% \text { atau } \\
120 \geq x>110 \%\end{array}$ & Kuning \\
\hline$x \geq 100 \%$ & $x \leq 100 \%$ & $90 \% \leq x \leq 110$ & Huas \\
\hline
\end{tabular}

Setelah menentukan IKU untuk setiap SS, organisasi perlu menetapkan target untuk setiap KPI. Target adalah suatu ukuran yang ingin dicapai dalam jangka waktu tertentu. Berkaitan dengan penerapan BSC, target umumnya ditetapkan untuk masa 1 tahun. Penentuan besarnya target dapat didasarkan pada beberapa hal seperti pencapaian tahun lalu (baseline), keinginan stakeholder, atau melihat kepada kondisi internal dan eksternal organisasi. Banyak penelitian telah dilakukan untuk menyelidiki efektifitas BSC dalam organisasi (Al-Hosaini, Fahmi Fadhl, 2015). Diamati bahwa banyak organisasi mengadopsi perspektif yang berbeda sesuai fungsinya sesuai dengan visi, misi dan tema strategis mereka. Beberapa peneliti telah menyoroti relevansinya dengan institusi Pendidikan Tinggi. Hasil studi mengidentifikasi perspektif yang relevan untuk Institusi Pendidikan Tinggi dan menyajikan analisis kontekstualnya. Bila diimplementasikan, ini dapat digunakan untuk memantau kinerjanya dan memungkinkan mereka menyesuaikan diri dengan tantangan baru yang muncul sebagai akibat penerapan strategi utama. Penelitian Strohhecker (2007) juga menyatakan penggunaan Balanced Scorecard terindikasi memberikan pengaruh terhadap peningkatan kinerja perusahaan. Bukti empiris dari literature mengkonfirmasi, bahwa perusahaan yang mengimplementasikan Balanced Scorecard telah menunjukkan pemulihan dari kondisi kinerja buruk dan mengembalikan situasi kehilangan mereka juga (Etim, 
R. S., Agara, 2011). Gacheri (Gacheri, 2011) dalam penelitiannya menemukan bahwa sebagian besar responden sepakat bahwa dampak sistem manajemen kinerja balanced scorecard terhadap kepuasan kerja karyawan penting dan akan lebih bernilai jika digunakan secara efektif. Efeknya umumnya dinilai moderat. Demikian juga studi (Narayanamma, 2017) yang meneliti peran balanced scorecard dalam meningkatkan kepuasan kerja karyawan, menyatakan untuk memperoleh manfaat penuh dari pendekatan scorecard, perusahaan harus bekerja lebih keras untuk mendapatkan karyawan menjalankan metode ini di semua tingkatan. Hasil penelitian menunjukkan bahwa terdapat hubungan positif antara balanced scorecard dan kepuasan kerja.

\section{Bolabasket}

Bolabasket adalaholahraga berkelompok yang terdiri atas dua tim beranggotakan masing-masing lima orang yang saling bertanding mencetak poin dengan memasukkan bola ke dalam keranjang lawan. Bolabasket sangat cocok untuk ditonton karena biasa dimainkan di ruang olahraga tertutup dan hanya memerlukan lapangan yang relatif kecil. Selain itu, bola basket mudah dipelajari karena bentuk bolanya yang besar, sehingga tidak menyulitkan pemain ketika memantulkan atau melempar bola tersebut.

Dalam bolabasket ada faktor penting yang menjadi penunjang yaitu pelatih. Pelatih adalah gelar atau sebutan yang memancarkan rasa hormat, respect, status, tanggung jawab. Fungsi dan peran seorang pelatih sangat erat hubungannya dengan capaian prestasi yang diukir oleh pemain. Pelatih adalah seorang yang harus tahu tentang semua kebutuhan yang menjadi dasar bagi terpenuhinya kondisi dimana pemain memiliki peluang untuk mencapai prestasi. Hubungan antara pelatih dengan pemain yang dibina harus merupakan hubungan yang mencerminkan kebersamaan pandangan dalam mewujudkan apa yang dicita-citakan. Seorang pelatih dituntut mampu mejalani profesinya dengan tidak semata mata bermodalkan dirinya sebagai bekas pemain, melainkan harus melengkapi dirinya dengan seperangkat kompetensi pendukung yang penting, diantaranya adalah kemampuan untuk mentransfer pengetahuan keolahragaannya kepada pemain secara lengkap baik dari segi teknik, taktik, maupun mental. Maka 
seorang pelatih harus mempersiapkan dirinya untuk menjadi contoh yang baik bagi pemain yang dilatihnya. Seorang pelatih yang baik memiliki kemampuan profesional sebagai pengajar, mengetahui cara memiliki kepribadian yang baik, dan memiliki karakter yang baik (Bazanov, 2007).

\section{Metode Penelitian}

Pendekatan penelitian yang digunakan adalah pendektan deskriptif kualitatif, dengan menggunakan metode observasi dan wawancara. Penelitian kualitatif adalah penelitian tentang riset yang bersifat deskriptif yang memberikan gambaran dan menjelaskan secara sistimatis (Alimudin, 2017). Data yang digunakan adalah data sekunder yang berkaitan dengan Perbasi Kota Surabaya yang didapatkan melalui situs Perbasi. Selain itu terdapat juga data primer hasil wawancara dengan informan, meliputi bidang pelatihan Perbasi Kota Surabaya dan hasil kuisioner yang dibagikan kepada pelatih-pelatih bolabasket di Kota Surabaya. Variabel-variabel dalam penelitian ini yang akan diteliti adalah kinerja organisasi yang diukur dengan empat perspektif balanced scorecard yaitu: (1) Perspektif keuangan; (2) Perspektif pelanggan; (3) Perspektif proses bisnis internal; dan (4) Perspektif pembelajaran dan pertumbuhan. Narasumber dalam penelitian ini disesuaikan dengan masing-masing perspektif Balanced Scorecard: (1) Perspektif Keuangan: Responden yang digunakan adalah Kepala bidang kepelatihan (2) Perspektif Pelanggan: Responden yang digunakan adalah pelatih dan atlet bolabasket yang terdaftar di Perbasi Kota Surabaya; (3) Perspektif Bis nis Internal: Responden yang digunakan adalah Kepala bidang kepelatihan; (4) Perspektif Pembelajaran dan Pertumbuhan: Responden yang digunakan adalah Kepala bidang kepelatihan.

Teknik analisis data yang digunakan dalam penelitian ini adalah Teknik deskriptif dengan melihat data-data fakta Perbasi Kota Surabaya dan menganalisis kinerja Perbasi Kota Surabaya berdasarkan perspektif-perspektif yang ada di dalam balanced scorecard. Tahapan analisis yang dilakukan meliputi pembobotan kinerja untuk menilai besaran angka/ indeks, yang terdiri dari: (1) Indeks Capaian Indikator Kinerja Utama (IKU); (2)Nilai Sasaran Strategis (NSS); (3)Nilai Kinerja Perspektif (NKP), dan (4) Nilai Kinerja Unit (NKU). Dalam 
analisis strategi digambarkan dan dijelaskan kondisi Perbasi Kota Surabaya dalam bentuk tabel serta analisis sederhana meliputi: (1) Penggambaran alur peta strategi Perbasi Kota Surabaya, dan (2) Penggambaran BSC model lengkap dengan sasaran strategis, pengukuran strategis dan performance.

\section{Hasil Penelitian}

\section{Profil Perbasi}

Persatuan Bola Basket Seluruh Indonesia merupakan organisasi pengatur olahraga bolabasket di Indonesia. Didirikan pada 23 Oktober 1952 oleh Tony Wen dan Wim Latumeten, atas permintaan Komite Olimpiade Indonesia (KOI) untuk menyusun organisasi olahraga bolabasket Indonesia. Sebelum disesuaikan dengan perbendaharaan bahasa Indonesia menjadi Perbasi, nama dari organisasi ini adalah Persatuan Basketball Seluruh Indonesia.

Perbasi menganut sistem vertikal berjenjang, yang dimulai dari tingkat perkumpulan, pengurus cabang (pengcab) Perbasi, pengurus daerah (pengda) Perbasi, sampai kepada pengurus pusat (PP) Perbasi. Dalam perjalanannya PP Perbasi telah beberapa kali berganti kepengurusan, dan saat ini sedang dipimpin oleh Danny Kosasih.

Salah satu pengcab Perbasi berada di Kota Surabaya. Perbasi Kota Surabaya saat ini dipimpin oleh Thung Siang Kheng, yang akan terus menjabat sebagai ketua umum sampai tahun 2016. Perbasi Kota Surabaya memiliki tugas dan tujuan yang sama dengan Perbasi pusat, yaitu:

1. Mengkoordinasikan, membina setiap bentuk kegiatan bolabasket di seluruh wilayah hukum Negara Kesatuan Republik Indonesia. Dalam rasa membangkitkan dan mengembangkan rasa cinta pada tanah air (nasionalisme).

2. Melalui kegiatan bolabasket secara tidak langsung membentuk manusia Indonesia seutuhnya yang sehat kuat jasmani maupun rohani, ulet, tangkas dan cerdas agar mempu berpartisipasi serta berkarya didalam pembangunan nasional.

3. Membina dan mengusahakan agar atlet dan anggota bolabasket mampu berprestasi secara berjenjang ditingkat wilayah/ daerah/ nasional/ regional/ 
internasional.

4. Memupuk serta membina persahabatan dan persaudaraan antar bangsa melalui kegiatan bolabasket yang diwujudkan dengan mengadakan hubungan dan menjadi anggota dari organisasi internasional antara lain melalui lomba/ kompetisi bolabasket dan kompetisi antar nagara.

5. Memupuk keahlian maupun ketrampilan untuk membuat alat peralatan Bola Basket.

Namun Perbasi Kota Surabaya hanya melakukan tugasnya di wilayah Kota Surabaya saja. Begitu pula dengan pengcab lainnya. Jika setiap pengcab dapat meningkatkan bolabasket di wilayahnya masing-masing, maka akan berpengaruh kepada tujuan Perbasi yaitu meningkatan prestasi bolabasket nasional.

\section{Identifikasi Masalah}

Masalah dalam penelitian ini teridentifikasi pertama kali dengan melihat prestasi bolabasket Kota Surabaya. Menurut Ricky Gunawan selaku bidang pengembangan Perbasi Kota Surabaya, prestasi bolabasket Kota Surabaya dapat dikatakan menurun 5 tahun terakhir. Menurunnya prestasi bolabasket Kota Surabaya dapat dinilai dari beberapa hal, seperti:

1. Tim bolabasket Ubaya yang sebagian besar anggotanya merupakan pelatih dan pemain Kota Surabaya, meskipun masih mendominasi tim universitas lain di Jawa Timur, tidak mampu meraih kembali juara nasional sejak terakhir kali di tahun 2013.

2. Tim bolabasket Jawa Timur KU-18 yang selalu didominasi oleh pemain dan pelatih dari Kota Surabaya, belum berhasil kembali menjadi juara nasional sejak terakhir kali di tahun 2011.

3. Jumlah pelatih dan pemain yang dipanggil untuk memperkuat tim nasional. Pada tahun 2013 ada 3 pemain dan 1 pelatih yang dipanggil untuk memperkuat timnas senior, namun di tahun 2015 hanya 1 pemain yang dipanggil kembali. Hal ini menunjukkan bahwa kualitas pemain dan pelatih bolabasket Kota Surabaya tidak lebih baik dibandingkan dengan daerah lainnya. 
Menurunnya kualitas pemain dan pelatih bolabasket Kota Surabaya merupakan 2 hal yang saling berkaitan. Meskipun tidak sepenuhnya menjadi tanggung jawab pelatih, namun pelatih memiliki pengaruh yang sangat besar terhadap kualitas seorang pemain. Pemain yang baik terbentuk melalui latihan yang baik, dan latihan yang baik dibentuk oleh pelatih yang baik. Jadi pelatih yang baik akan menghasilkan pemain yang baik. Pelatih yang baik akan terbentuk melalui pengalaman dan proses belajar yang panjang. Dibutuhkan informasi-informasi mengenai bolabasket yang akan membantu pelatih dalam mengembangkan kemampuan melatih mereka. Perbasi Kota Surabaya, khususnya bidang pelatihan merupakan organisasi yang harus membantu para pelatih bolabasket di Kota Surabaya agar bisa menjadi pelatih yang baik, melalui tugas dan program kerja yang sudah mereka rencanakan. Seperti yang telah dijelaskan pada sub bab sebelumnya, bidang pelatihan Perbasi Kota Surabaya memiliki beberapa tugas dan program kerja, seperti pendataan pelatih, penataan administrasi lisensi pelatih, menyelenggarakan penataran dan penyegaran pelatih, memberikan informasi yang diperlukan oleh pelatih dan melakukan pembinaan berkelanjutan bagi pelatih. Namun dari kelima tugas dan program tersebut Perbasi Kota Surabaya hanya rutin melaksanakan penataran dan penyegaran pelatih saja. Itu pun terakhir kali dilaksanakan pada tahun 2013. Sedangkan untuk tugas dan program lainnya tidak dilakukan secara rutin seperti penataran dan penyegaran pelatih, bahkan hampir tidak pernah sama sekali. Hasil kuisioner kepada pelatih-pelatih di Kota Surabaya yang dapat dilihat pada lampiran B, menunjukkan bahwa $75,7 \%$ dari 70 responden merasa bahwa pembinaan yang diberikan oleh Perbasi Kota Surabaya masih belum bisa membantu mereka dalam memenuhi kebutuhan sebagai pelatih. Tempat dan waktu merupakan dua hal yang sering menjadi kendala dalam menjalankan tugas dan program bidang pelatihan. Hal ini juga menjadi penyebab salah satu program Perbasi Kota Surabaya yaitu sarasehan tidak bisa dilanjutkan. Tempat dan waktu terkadang menjadi kendala bagi Perbasi untuk memberikan pembinan yang baik kepada para pelatih di Kota Surabaya. Perbasi Kota Surabaya sebagai organisasi yang bertanggung jawab penuh terhadap olahraga bolabasket masih belum bisa bekerja secara maksimal 
dalam mengembangakan pelatih bolabasket Kota Surabaya.

Berdasarkan hasil kuisioner yang dapat dilihat pada lampiran B, 85,7\% para pelatih juga mengalami kesulitan dalam mendapatkan informasi-informasi kepelatihan yang dapat menunjang kemajuan mereka. Salah satu kesulitan yang mereka ungkapkan melalui kusioner adalah tidak ada buku atau video berisi informasi-informasi khusus dalam bolabasket, seperti strategi untuk memecahkan lawan dengan pertahanan full court press, jenis-jenis pick and roll, transisi dari defense ke offense dan masih banyak lagi, yang dipublikasikan di Indonesia. Meskipun buku dan video mengenai bolabasket sudah bisa dibeli melalui internet, namun tetap kebanyakan pelatih tidak dapat membelinya karena alasan dana dan bahasa. Selain itu, membeli buku atau video mengenai bolabasket melalui internet membutuhkan waktu yang cukup lama dalam pengirimannya. Selain tidak dijual di Indonesia, tidak semua informasi-informasi spesifik mengenai bolabasket juga tersedia dalam buku dan video. Sering kali informasi-informasi tersebut hanya dimiliki oleh pelatih-pelatih yang sudah berpengalaman. Adanya internet memang memberi peluang bagi para pelatih untuk dapat mencari informasi-informasi yang mereka perlukan sebagai pelatih, namun berdasarkan hasil kuisioner sebagian dari pelatih di Kota Surabaya mengalami kesulitan dalam memahami informasi yang mereka dapatkan melalui internet, yang seringkali juga disebabkan oleh perbedaan bahasa. Informasi-informasi yang baik mengenai bolabasket lebih banyak diangkat dengan menggunakan bahasa Inggris. Selain itu informasi-informasi yang dibagikan melalui internet juga tidak terstruktur, sehingga membuat informasi semakin sulit untuk diserap. Kesalahan dalam memahami isi informasi menyebabkan mereka hanya mengikuti dan menirukannya tanpa mengerti maksud dan tujuan dari informasi tersebut, sehingga penerapannya menjadi tidak berdampak.

Melalui hasil kuisioner juga dapat diketahui bahwa para pelatih memerlukan teman untuk berdiskusi dan berbagi (sharing). Mereka menyadari bahwa sharing dapat membuka wawasan mereka dalam melatih bolabasket dan membantu mereka dalam saat kesulitan memahami sebuah informasi. Melalui sharing, tidak hanya pengetahuan eksplisit yang bisa dibagikan dan didapatkan, 
tetapi juga pengetahuan tacit, seperti pengalaman pelatih dalam menangani pemain atau tim, pengalaman saat menghadapi lawan tertentu, pengalaman saat melatih tim kota, provinsi atau nasional, dan pengalaman lainnya yang belum tentu pernah dialami oleh pelatih lainnya. Pengetahuan tacit merupakan aset paling dinamis yang dimiliki seseorang. Jika ditemukan dan dibagikan melalui knowledge sharing yang efektif, maka dapat mengembangkan inovasi dan meningkatkan produktifitas [SMI05]. Sayangnya knowledge sharing belum menjadi sebuah kebiasaan diantara pelatih-pelatih di Kota Surabaya. Sampai saat ini belum ada media yang mampu secara optimal menyediakan tempat bagi para pelatih untuk dapat bertanya atau berbagi pengetahuan dan pengalaman mereka. Tidak ada juga pelatih yang memiliki situs pribadi yang digunakan untuk membagikan pengalaman mereka dalam melatih bolabasket. Sebagian dari mereka memang sempat beberapa kali berdisuksi dengan pelatih lainnya, namun karena pengetahuan yang dibagikan melalui diskusi tidak terstruktur, maka seringkali mereka lupa dan tidak bisa memahami dengan jelas inti dari pengetahuan yang dibagikan. Padahal jika kita melibatkan orang yang kita percaya, maka besar kemungkinan knowledge sharing yang optimal akan terjadi. Mereka yang dilibatkan seringkali dapat memberi rekomendasi saat mengambil keputusan, bahkan memberi solusi terhadap suatu masalah. Hal tersebut bisa terjadi karena orang yang dilibatkan adalah orang pada bidang yang sama dan dapat dipercaya, sehingga akan memberikan kepastian dan keamaan atas rekomendasi-rekomendasi yang diberikan.

Melalui masalah-masalah yang telah diidentifikasi, dapat diketahui bahwa para pelatih bolabasket di Kota Surabaya tidak memiliki media untuk berbagi, dan referensi-referensi untuk mendapatkan informasi kepelatihan, sehingga menghambat informasi-informasi tersebut untuk sampai ke tangan para pelatih bolabasket di Kota Surabaya. Akhirnya mereka kesulitan untuk mengembangkan kemampuan mereka sebagai pelatih dan tidak dapat menciptakan latihan yang baik, yang dapat mengembangkan pemain atau tim yang dilatihnya. Selain dapat berdampak kepada karir kepelatihan mereka, masalah tersebut juga dapat berdampak terhadap prestasi bolabasket Kota Surabaya. 


\section{Rancangan Peta Strategi Perbasi Kota Surabaya}

Berikut ini akan ditampilkan rancangan peta strategi Perbasi Kota Surabaya yang dibuat berdasarkan data primer (hasil wawancara) dan analisis data sekunder yang dilakukan, dan dengan membandingkannya dengan teori yang ada:

Tabel 2. Rancangan Peta Strategi Perbasi Kota Surabaya

\begin{tabular}{|c|c|c|}
\hline $\begin{array}{l}\text { Pembelajaran } \\
\& \\
\text { Pertumbuhan }\end{array}$ & $\begin{array}{l}\text { Peningkatan mutu SDM } \\
\text { (Pelatih) }\end{array}$ & $\begin{array}{l}\text { Visi: } \\
\text { Meningkatkan prestasi olahraga } \\
\text { bolabasket melalui pembinaan yang }\end{array}$ \\
\hline $\begin{array}{l}\text { Proses Bisnis } \\
\text { Internal }\end{array}$ & 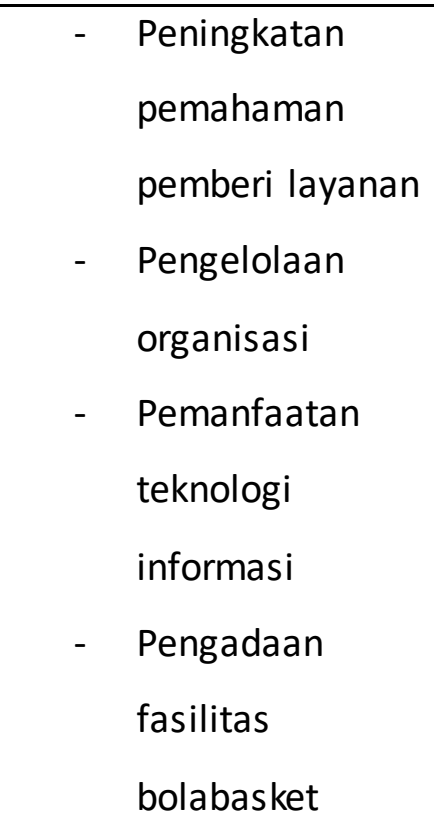 & $\begin{array}{l}\text { berbasis sekolah. } \\
\text { Misi: } \\
\text { 1. Menjadikan organisasi yang efektif, } \\
\text { merangkul semua pihak, dengan } \\
\text { personil yang kompeten, fleksibel } \\
\text { sesuai kebutuhan sehingga tercipta } \\
\text { komunikasi yang lancar antara pusat } \\
\text { dan daerah. } \\
\text { 2. Memastikan terjadinya kompetisi } \\
\text { tahunanyang regulerdanterjadwal. } \\
\text { 3. Melakukan harmonisasi program } \\
\text { kompetisi dan pembinaan dengan jalur }\end{array}$ \\
\hline Pelanggan & $\begin{array}{ll}- & \text { Kepuasan } \\
& \text { stakeholder } \\
\text { - } & \text { Peningkatan } \\
& \text { kualitas pelatih }\end{array}$ & $\begin{array}{l}\text { klub dan jalur sekolah dengan tujuan } \\
\text { akhir reorientasi pembinaan bola } \\
\text { basket berbasis sekolah. } \\
\text { 4. Meningkatkan prestasi Timnas /wakil }\end{array}$ \\
\hline Keua & 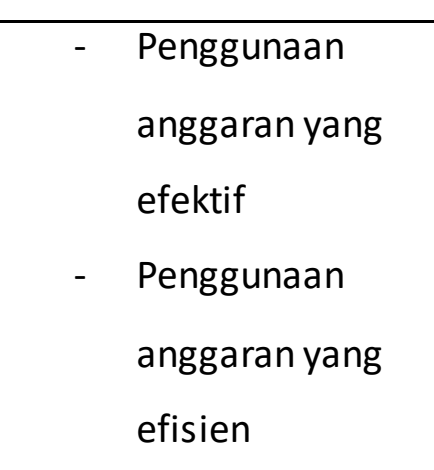 & $\begin{array}{l}\text { Indonesia di ajang ASEAN dengan } \\
\text { targetyang meningkat. } \\
\text { 5. Melakukan perbaikan kualitas SDM } \\
\text { yangmerata di semua daerah. } \\
\text { 6. Menyediakan dukungan pendanaan } \\
\text { yang pasti melalui dana kas, } \\
\text { pemerintah pusat, pemda, donatur }\end{array}$ \\
\hline
\end{tabular}




\begin{tabular}{|l|l|l|}
\hline & & dan sponsor. \\
\hline
\end{tabular}

Berdasarkan tabel 2 dapat diketahui bahwa peta strategi Perbasi Kota Surabaya terdiri dari empat perspektif balanced scorecard dan masing-masing perspektif terdiri dari satu atau beberapa sasaran strategi (SS), yaitu:

1. Perspektif keuangan

a. Penggunaan anggaran yang efisien, yaitu dana yang telah dianggarkan digunakan sesuai peruntukannya (tepat sasaran)

b. Penggunaan anggaran yang efektif, yaitu tingkat pencapaian tolak ukur kinerja dari setiap kegiatan sesuai dengan target yang telah ditetapkan oleh Perbasi Kota Surabaya.

2. Perspektif pelanggan

a. Kepuasan stakeholder, yaitu akibat dari meningkatnya pelayanan yang dilakukan oleh Perbasi Kota Surabaya terhadap pelatih, pemain dan klub yang terdaftar.

b. Peningkatan kualitas program pelatihan, yaitu peningkatan akses terhadap informasi-informasi kepelatihan bolabasket, serta menambah program-program untuk membantu meningkatkan kualitas pelatih.

3. Perspektif proses bisnis internal

a. Peningkatan pemahaman pemberi layanan, yaitu program-program yang dibuat untuk memperbaiki kualitas pemberian layanan terhadap pelatih bolabasket di Kota Surabaya.

b. Pengelolaan organisasi, yaitu pengelolaan proses bisnis dan alur pelayanan, serta dasar hukum yang digunakan dalam menjalani proses bisnis Perbasi Kota Surabaya.

c. Pemanfaatan teknologi informasi, yaitu meningkatkan kinerja Perbasi Kota Surabaya dengan memanfaatkan teknologi dalam menyimpan, mengolah dan menyebarkan data.

d. Pengadaan fasilitas bolabasket, yaitu peningkatan fasilitas-fasilitas bolabasket di Kota Surabaya, seperti lapangan dan bola untuk 
berlatih atau bertanding.

4. Perspektif pembelajaran dan pertumbuhan

a. Peningkatan mutu SDM (pelatih), yaitu program-program yang dilakukan oleh Perbasi Kota Surabaya untuk meningkatkan kemampuan dan kualitas para penatar (yang memberi pelatihan) dan pelatih (peserta didik).

\section{KESIMPULAN DAN SARAN}

Berdasarkan rancangan analisis pencapaian strategi menggunakan balanced scorecard pada strategi yang digunakan Perbasi Kota Surabaya dalam meningkatkan prestasi bolabasket Kota Surabaya melalui peningkatan kualitas pelatih, telah tercapai dengan baik. Namun masih terdapat beberapa kendala di lapangan, yang pada akhirnya menghambat proses pelaksanaan program-program bagi para pelatih bolabasket di Kota Surabaya. Selanjutnya, Perbasi Kota Surabaya perlu untuk memaksimalkan proses perencanaan anggaran sehingga anggaran yang telah ditetapkan akan dapat lebih efektif dan efisien. Selain itu diperlukan juga evaluasi secara rutin terhadap pelaksanaan program-program yang ada di Perbasi Kota Surabaya, dalam rangka meningkatkan persentase realisasi anggaran. Setelah melakukan penelitian, saran yang dapat diusulkan untuk pengembangan yang lebih lanjut adalah melakukan penelitian pengaruh dari masing-masing perspektif terhadap capaian kinerja dengan memasukan unsur lingkungan eksternal.

\section{DAFTAR REFERENSI}

Alimudin, A. (2017). ANALISIS PENCAPAIAN STRATEGI MENGGUNAKAN BALANCED SCORECARD. Jurnal Pendidikan Ekonomi \& Bisnis (Edisi Elektronik), 5(2), 178-194.

Bazanov, B. (2007). Integrative approach of the technical and tactical aspects in basketball coaching. Abstract. Tallinn University. Dissertations on Social Sciences, 30(January), 1736-3675. 
Hunger, D., \& Thomas. L. Wheelen. (2004). Essentials of Strategic Project Management. International Journal of Project Management, 18(2), 93-103. https://doi.org/10.1016/S0263-7863(98)00076-3 


\section{LAMPIRAN A \\ REKAPITULASI WAWANCARA}

\section{Respoden:}

- Tuan Arifin selaku staf pelatih selaku anggota bidang pelatihan dari PERBASI Kota Surabaya

\section{Keterangan:}

- Wawancara dilakukan 1 kali, yaitu di Lapangan Basket Tri Lomba Juang.

- $\mathbf{T}=$ Tanya, $\mathbf{J}=$ Jawab

T: Apakah tugas anda sebagai anggota bidang pelatihan?

J: Tugas dari bidang pelatihan adalah melakukan pembinaan rutin bagi pelatih-pelatih yang terdaftar di kota Surabaya. Selain pembinaan, tugas dari bidang pelatihan PERBASI Kota Surabaya adalah menentukan pelatih untuk memimpin tim bolabasket kota Surabaya dan membuat kebijakan dan peraturan permainan untuk pertandingan yang diadakan oleh PERBASI.

T: Berapakah jumlah pelatih yang terdaftar di kota Surabaya saat ini?

J: Saat ini pelatih yang terdaftar/ memiliki lisensi pelatih di kota Surabaya ada 124 orang.

T: Kegiatan apa saja yang dilakukan oleh PERBASI kota Surabaya dalam pembinaan pelatih?

J: Ada 2 kegiatan yang selalu dilakukan oleh PERBASI kota Surabaya. Pertama penataran pelatih, yang ditujukan bagi para pelatih yang ingin mendapatkan lisensi untuk dapat melatih sebuah tim. Kedua penyegeraan pelatih, yang bertujuan untuk memperpanjang masa aktif lisensi yang dimiliki oleh pelatih. Kedua kegiatan tersebut rutin dilakukan, masing-masing 1-2 kali dalam 1 tahun.

T: Menurut anda apakah penataran dan penyegaran yang dilakukan oleh PERBASI kota Surabaya sudah cukup untuk memenuhi kebutuhan para pelatih? 
J: Penataran dan penyegeran pelatih memang masih belum cukup dalam memenuhi kebutuhan sebagai pelatih bolabasket. Hanya kondisi internal PERBASI kota Surabaya yang tidak kondusif membuat saya sebagai anggota bidang pelatihan juga sulit untuk bekerja

T: Apakah PERBASI kota Surabaya pernah mengadakan kegiatan lain selain penataran dan penyegaran?

J: Sebenarnya PERBASI kota Surabaya pernah mengadakan sarasehan, dengan tujuan mengumpulkan seluruh pelatih yang ada di kota Surabaya untuk saling berdiskusi dan berbagi tentang bolabasket, namun kegiatan tersebut hanya sempat berjalan beberapakali.

T: Apa penyebab gagalnya acara sarasehan tersebut?

J: Kegiatan sarasehan tidak dapat berjalan karena peserta pelatih yang datang terlalu sedikit. Sebagian besar dari mereka beralasan bahwa kendala tempat dan waktu yang menyulitkan mereka untuk bisa hadir ke kegiatan sarasehan

T: Apakah sumber/ referensi yang bisa digunakan oleh para pelatih untuk memenuhi kebutuhan mereka sebagai pelatih?

J: Sebenarnya sangat sulit untuk mendapatkan referensi mengenai bolabasket di Indonesia, apalagi tidak ada buku atau video mengenai bolabasket yang dipublikasikan di Indonesia. Meskipun sekarang sudah bisa mendapatkan referensi mengenai bolabasket melalui internet, namun yang saya tahu banyak pelatih yang kesulitan dalam mencerna informasi yang mereka dapatkan, karena keterbatasan kemampuan mereka. Jadi bisa dikatakan bahwa tidak ada sumber/ referensi yang bisa digunakan oleh para pelatih untuk memenuhi kebutuhan mereka.

T: Apakah kurangnya pembinaan pelatih dan sulitnya mereka untuk mendapatkan referensi berpengaruh kepada prestasi bolabasket kota Surabaya saat ini?

J: Hal ini tentu bisa berpengaruh kepada prestasi bolabasket kota Surabaya. Salah 
satu pengaruh yang bisa terlihat adalah tim bolabasket Jawa Timur tidak berhasil menjadi juara di 4 tahun terakhir kejuaraan nasional, padahal sebagian besar dari tim ini adalah atlet dan pelatih kota Surabaya. Lalu kota Surabaya juga hanya bisa menyumbanga 1 atlet pada ajang SEA GAMES tahun 2015 di Singapura. Hal-hal tersebut dapat menjadi indikasi menurunnya prestasi bolabasket kota Surabaya dan pelath merupakan faktor yang sangat berpengaruh dalam hal tersebut. 


\section{LAMPIRAN B \\ REKAPITULASI KUISIONER}

\section{Kuisioner untuk Pelatih Bolabasket di Kota Bandung}

Deskripsi Formulir

Lisensi ${ }^{*}$

Klub $^{\star}$

1. Apakah pembinaan yang diberikan oleh PERBASI Kota Bandung telah memenuhi kebutuhan anda sebagai pelatih?

Ya

Tidak

2.Selain penataran dan penyegaran pelatih, kegiatan apa yang anda ketahui sebagai bentuk pembinaan dari PERBASI Kota Bandung bagi para pelatih?

3. Apakah penataran dan penyegaran pelatih yang dilakukan oleh PERBASI Kota Bandung sudah cukup untuk memenuhi kebutuhan dan meningkatkan kualitas pelatih?"

Ya

Tidak

4. Media apa yang selama ini anda gunakan untuk memenuhi kebutuhan anda sebagai pelatih bolabasket?* (Bisa memilih lebih dari satu)

$\square$ Buku

$\square$ Video

$\square$ Internet

Pengalaman

Diskusi

Seminar

Penataran

Penyegaran

$\square$ Yang lain:

5. Apakah media yang anda gunakan saat ini sudah cukup untuk memenuhi kebutuhan anda sebagai pelatih?*

Ya

Tidak

6. Informasi/ data apa saja yang anda perlukan untuk memenuhi kebutuhan anda sebagai pelatih?*

7. Apakah anda mengalami kesulitan dalam mencari informasi/ data tersebut?"

- Ya

Tidak 
8. Jika ya, kesulitan apa yang anda alami?

(Bisa memilih lebih dari satu)

$\square$ Kesulitan mencari informasi

Kesulitan dalam memahami isi referensi

Biaya

Yang lain:

9. Apakah anda pernah/ sering melakukan sharing/ diskusi dengan pelatih lain?*

Ya

Tidak

Jika ya, apakah dengan melakukan sharing/ diskusi dapat menambah wawasan anda dalam melatih?

Ya

Tidak

10. Apakah anda tahu tentang kegiatan sarasehan yang diadakan oleh PERBASI Kota Bandung?*

Ya

Tidak

11. Jika ya, pernahkah anda mengikuti kegiatan sarasehan tersebut?

Ya

Tidak

12. Apa alasan anda tidak mengikuti kegiatan sarasehan tersebut?

$\square$ Kendala tempat

$\square$ Kendala waktu

$\square$ Yang lain:

13. Apa pendapat anda tentang kegiatan sarsehan?

14. Menurut anda, apakah kegiatan sarasehan dapat menambah wawasan dan meningkatkan kualitas anda sebagai pelatih?*

Ya

Tidak 
Dalam mencari sample digunakan rumus slovin:

$\mathrm{n}=\mathrm{N} / \mathrm{N}(\mathrm{d})^{\wedge} 2+1$

Maka dengan populasi pelatih di kota Surabaya (124), didapat sample sebesar:

$\mathrm{n}=124 / 124(0.05)^{\wedge} 2+1$

$=95$

\begin{tabular}{|c|c|c|c|c|}
\hline NAMA & & & & \\
\hline & $\mathrm{C}$ & $\mathrm{B}$ & $\mathrm{A}$ & FIBA \\
\hline Agus tayudin rohimat & $\mathrm{X}$ & & & \\
\hline Suki & & $\mathrm{X}$ & & \\
\hline Christian Jonathan & & $\mathrm{X}$ & & \\
\hline Marlin & & $\mathrm{X}$ & & \\
\hline Arifin & & $\mathrm{X}$ & & \\
\hline Bayu Ginandjar N & & $\mathrm{X}$ & & \\
\hline Achmad sobari & & $\mathrm{X}$ & & \\
\hline Andi Soenaryo & & $\mathrm{X}$ & & \\
\hline Yudhistira Suparman & & $\mathrm{X}$ & & \\
\hline Roni & & $\mathrm{X}$ & & \\
\hline Kentdry Cahyadi & $\mathrm{X}$ & & & \\
\hline Rizki Ramadhan & $\mathrm{X}$ & & & \\
\hline Marisa Noviyanti Fajra Ilsya & $\mathrm{X}$ & & & \\
\hline R Yudistira & & & $\mathrm{X}$ & \\
\hline Ira yustina & & $\mathrm{X}$ & & \\
\hline William & $\mathrm{X}$ & & & \\
\hline Peny & $\mathrm{X}$ & & & \\
\hline Ricky Gunawan & & & & $\mathrm{X}$ \\
\hline Daniel Siswanto & & $\mathrm{X}$ & & \\
\hline Hendra Kurniawan & & $\mathrm{X}$ & & \\
\hline andry & $\mathrm{X}$ & & & \\
\hline Devid Rooland & $\mathrm{X}$ & & & \\
\hline Herman maulana & & $\mathrm{X}$ & & \\
\hline Acep Farid Mulyana & $\mathrm{X}$ & & & \\
\hline Adi Rahadian & $\mathrm{X}$ & & & \\
\hline Aep Saepudin & $\mathrm{X}$ & & & \\
\hline Andri Malay & $\mathrm{X}$ & & & \\
\hline Atang Purnama & $\mathrm{X}$ & & & \\
\hline B E Partomuan $\mathrm{N}$ & $\mathrm{X}$ & & & \\
\hline Dally Nur Arif & $\mathrm{X}$ & & & \\
\hline Dede Rusdiana & $\mathrm{X}$ & & & \\
\hline Deni Rahmanudin & $\mathrm{X}$ & & & \\
\hline Elin Herlina & $\mathrm{X}$ & & & \\
\hline Ngiap Kian Ming & & $\mathrm{X}$ & & \\
\hline Gardea & $\mathrm{X}$ & & & \\
\hline
\end{tabular}




\begin{tabular}{|c|c|c|c|c|}
\hline Geta Septiadi & $\mathrm{X}$ & & & \\
\hline Hendry Gunadi & $\mathrm{X}$ & & & \\
\hline $\begin{array}{l}\text { Khaerul Himmah } \\
\text { Prawirawijaya }\end{array}$ & & $\mathrm{X}$ & & \\
\hline Maman Jumansyah & & $\mathrm{X}$ & & \\
\hline Martin Seahan & $\mathrm{X}$ & & & \\
\hline Bambang Yudi $\mathrm{P}$ & & $\mathrm{X}$ & & \\
\hline Wiliam & $\mathrm{X}$ & & & \\
\hline Yandhi Fachrudin & $\mathrm{X}$ & & & \\
\hline Dri Januar & & $\mathrm{X}$ & & \\
\hline Eri Setiawan & & $\mathrm{X}$ & & \\
\hline Agus Sutisno & $\mathrm{X}$ & & & \\
\hline Amin Muhaemin & $\mathrm{X}$ & & & \\
\hline Andi Sumarna & $\mathrm{X}$ & & & \\
\hline Dudi Pamungkas & & $\mathrm{X}$ & & \\
\hline Sianny Lieyuniati & $\mathrm{X}$ & & & \\
\hline Susana Iffoni & & $\mathrm{X}$ & & \\
\hline Nurul Inayah & $\mathrm{X}$ & & & \\
\hline Rachmat Fadilah & $\mathrm{X}$ & & & \\
\hline Rizal Adhari & $\mathrm{X}$ & & & \\
\hline Sasongko Widiarso & $\mathrm{X}$ & & & \\
\hline Sofyan Syafril & & $\mathrm{X}$ & & \\
\hline Sukrisna & & $\mathrm{X}$ & & \\
\hline Sugih Candra Kayat & $\mathrm{X}$ & & & \\
\hline Teguh Fajar Putra Utama & $\mathrm{X}$ & & & \\
\hline Topan Hendrayana & $\mathrm{X}$ & & & \\
\hline $\begin{array}{l}\text { Triyan Krishandra Jeffri } \\
\text { Yatin }\end{array}$ & $\mathrm{X}$ & & & \\
\hline William Andrianus & $\mathrm{X}$ & & & \\
\hline Windy Kristianti & $\mathrm{X}$ & & & \\
\hline Yudana Setia & $\mathrm{X}$ & & & \\
\hline Taufik Shaleh & & $\mathrm{X}$ & & \\
\hline Pandu Gunawan & $\mathrm{X}$ & & & \\
\hline Yosep Norida Kuncara & & $\mathrm{X}$ & & \\
\hline Ricky Hidayat & $\mathrm{X}$ & & & \\
\hline Fachrul Rozi & & $\mathrm{X}$ & & \\
\hline Rizky Koeswijaya & $\mathrm{X}$ & & & \\
\hline TOTAL & 42 & 26 & 1 & 1 \\
\hline
\end{tabular}


1. Apakah pembinaan yang diberikan oleh PERBASI Kota Bandung telah memenuhi kebutuhan anda sebagai pelatih?

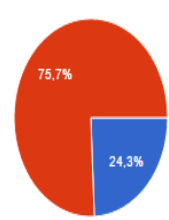

Ya $17 \quad 24.3 \%$

Tidak $\quad 53 \quad 75.7 \%$

2.Selain penataran dan penyegaran pelatih, kegiatan apa yang anda ketahui sebagai bentuk pembinaan dari PERBASI Kota Bandung bagi para pelatih?

Penataran, sarasehan

Kompetisi dari level antar klub sampai ketingkat lebih atas (popda, kejurda, kejunnas, porda) Sarasehan antar pelatih, pelatih dengan wasit

Sarasehan

Sarasehan pelatih. Tapi sepertinya sudah lama tidak diselenggarakan. Sosialisasi rules terbaru saja belum dilaksanakan, mungkin ini bisa jadi referensi

Pertemuan antar pelatih

tidak ada

Coaching clinic

3. Apakah penataran dan penyegaran pelatih yang dilakukan oleh PERBASI Kota Bandung sudah cukup untuk memenuhi kebutuhan dan meningkatkan kualitas pelatih?

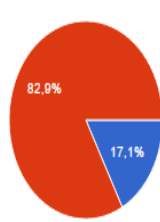

$\begin{array}{rrr}Y a & 12 & 17.1 \%\end{array}$

Tidak $58 \quad 82.9 \%$

4. Media apa yang selama ini anda gunakan untuk memenuhi kebutuhan anda sebagai pelatih bolabasket?

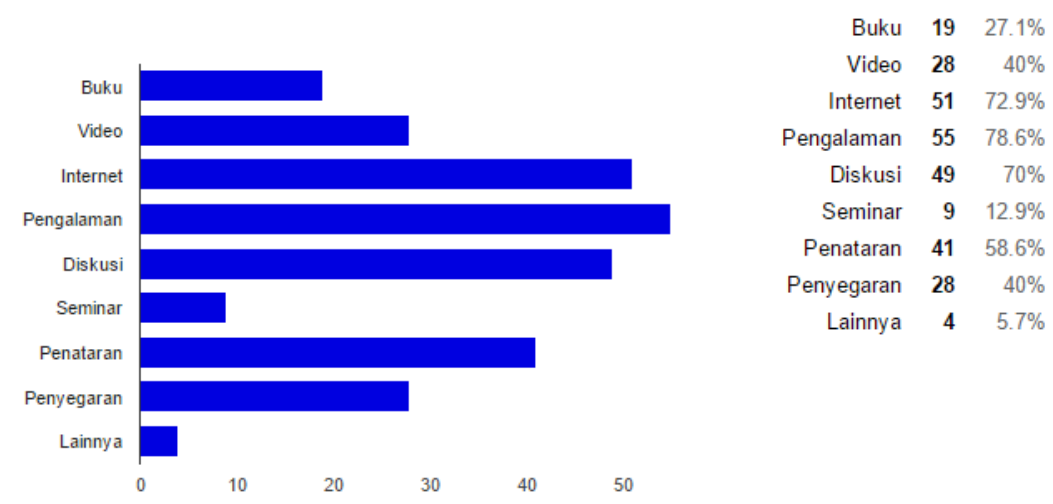

5. Apakah media yang anda gunakan saat ini sudah cukup untuk memenuhi kebutuhan anda sebagai pelatih?

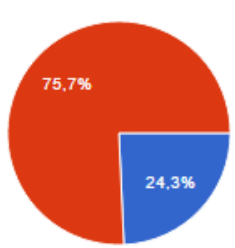

Ya $17 \quad 24.3 \%$

Tidak $53 \quad 75.7 \%$ 
6. Informasi/ data apa saja yang anda perlukan untuk memenuhi kebutuhan anda sebagai pelatih?

Data diri anggota

Sharing ilmu Dan komunikasi serta kerja sama dengan sesama pelatih

Perkembangan olahraga

Perkembangan olahraga bola basket. Metode pelatihan. Aturan olahraga bola basket.

Cara melatih

Peraturan dari olahraga

Data pemain, statistik perorangan , statistik tim

7. Apakah anda mengalami kesulitan dalam mencari informasi/ data tersebut?

$$
\text { Ya } \quad 60 \quad 85.7 \%
$$

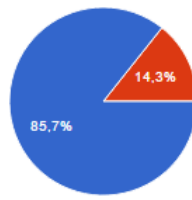

Tidak $\quad 10 \quad 14.3 \%$

8. Jika ya, kesulitan apa yang anda alami?
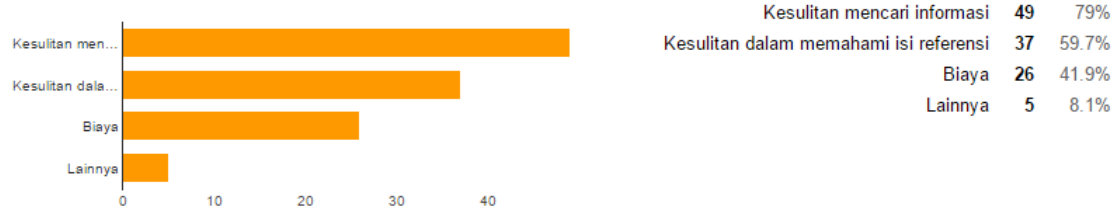

9. Apakah anda pernah/ sering melakukan sharing/ diskusi dengan pelatih lain?

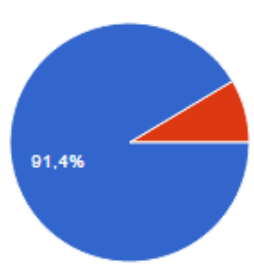

Ya $64 \quad 91.4 \%$

Tidak $6 \quad 8.6 \%$

Jika ya, apakah dengan melakukan sharing/ diskusi dapat menambah wawasan anda dalam melatih?

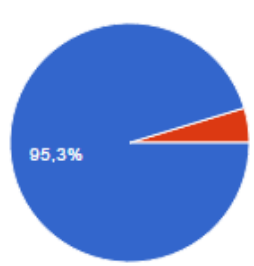

Ya $61 \quad 95.3 \%$

Tidak $3 \quad 4.7 \%$

10. Apakah anda tahu tentang kegiatan sarasehan yang diadakan oleh PERBASI Kota Bandung?

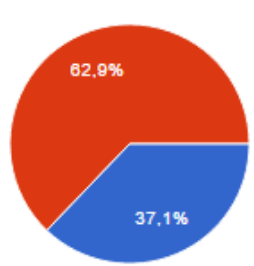

Ya $26 \quad 37.1 \%$

Tidak $44 \quad 62.9 \%$ 
11. Jika ya, pernahkah anda mengikuti kegiatan sarasehan tersebut?

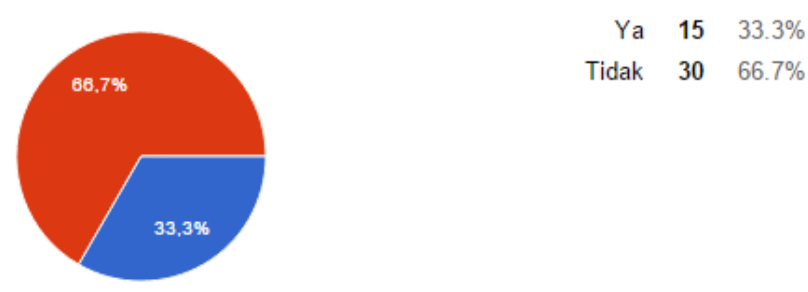

12. Apa alasan anda tidak mengikuti kegiatan sarasehan tersebut?

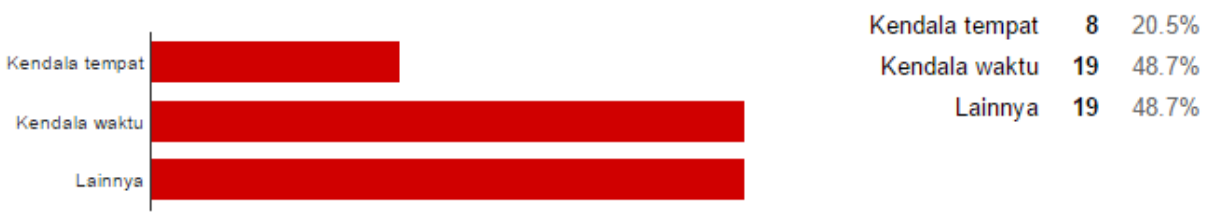

\section{Apa pendapat anda tentang kegiatan sarsehan?}

Berguna utk menambah wawasan dan mendapatkan ide2 baru Sangat bagus

Memberikan wawasan baru akan perkembangan olahraga

Tidak rutin dilaksanakan dan tidak fokus dalam pembahasan materi di setiap sesinya.

Membantu menambah pengetahuan

Kegiatan yang sangat memperluas wawasan

Meningkatkan kualitas saya sebagai pelatih

14. Menurut anda, apakah kegiatan sarasehan dapat menambah wawasan dan meningkatkan kualitas anda sebagai pelatih?

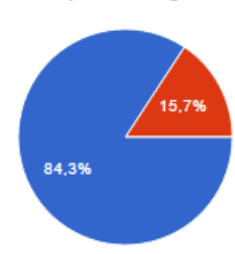

Ya $59 \quad 84.3 \%$

Tidak $11 \quad 15.7 \%$ 